\title{
生物共生護岸における生息場としての機能の変遷
}

\section{Change in the Habitat values on the Habitable Seawalls for Marine Organisms}

\author{
田中ゆう子 ${ }^{1}$ ・鈴木秀男 ${ }^{2}$
}

\section{Yuko TANAKA and Hideo SUZUKI}

\begin{abstract}
A seawall construction project aiming at habitat creation in inner Tokyo Bay was described. In this project, various seawalls such as a rubble-type seawall with a slope and vertical seawall with precast plates were designed for providing a new habitat. The habitat values of the seawalls were evaluated on the basis of various ecological characteristics of attached organisms on the seawalls, which included biological interaction and its spatial and temporal changes.
\end{abstract}

\section{1. はじめに}

我が国の生物多様性国家戦略2010では, 森, 里, 川, 海のつながりを確保しつつ, 海洋の保全・再生を強化す ることが基本戦略の一つとされる．最近，老朽化した護 岸や耐震強化が必要な護岸などを生物共生護岸へ転換さ せ，海域環境の改善を図る取り組みが推進されている. 生物共生護岸には, 周辺海域における生物多様性や水産 資源の保全，市民の憩いの場，環境学習の場などの機能 が期待されている.これまでに生物との共生を目的とし た環境創出についてはさまざまな報告があるが，護岸を 利用して創出した生息場が，造成後長い期間を経てどの ように変遷したのかを報告している事例はほとんど無い.

図-1に示す横須賀港内の埋立護岸では，1992～1994年 度に，生物の生息・生育に配慮した構造を取り入れた生 物共生護岸が造成された。生物共生護岸は，付着生物の

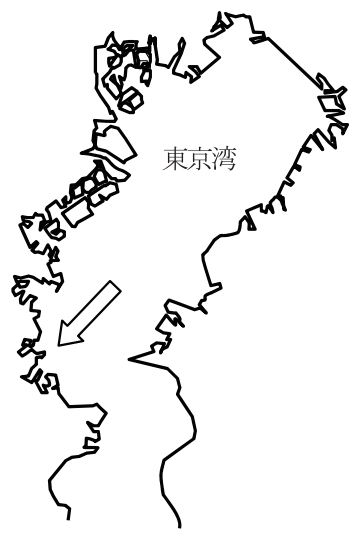

図-1 調查護岸の位置
生息を促す凸凹のあるプレキャストコンクリート板を取 り付けた図-2の護岸 (以後, 棚護岸) と図-3に示す海藻 の繁茂を考慮して傾斜を設けた石積護岸の2夕イプであ る。施工直後の1995～1996年にモニタリング調査を実 施し, 護岸の形状による効果の違いを定量的に比較した. その結果, プレキャスト板を設置していない直立護岸部 や棚護岸ではムラサキイガイが大量に付着し，生物多様 性は低い状況にあった。一方, 石積護岸では海藻が繁茂 し，それにより多様な生物が生息し，良好な生物の生息 環境として観察された。しかし，その後は継続して調査 を行っていなかった，本研究では造成直後の調査から約 15 年を経て, 生物共生護岸における形状の違いが生物群

(a)
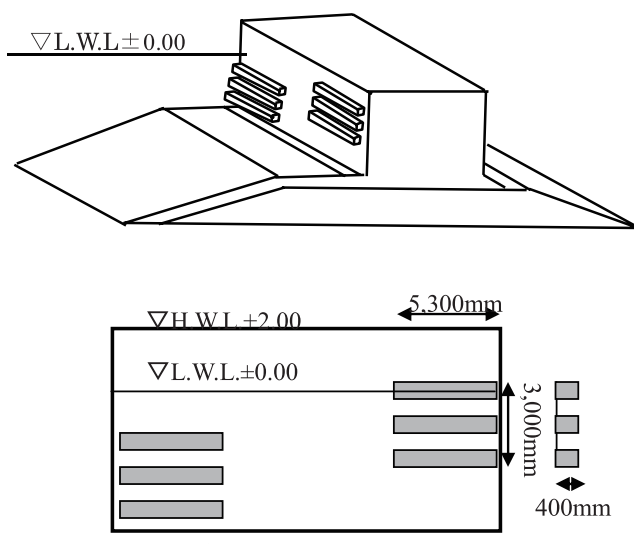

(b)

図-2 棚護岸形状（a：プレキャスト板位置，b：正面・断面）

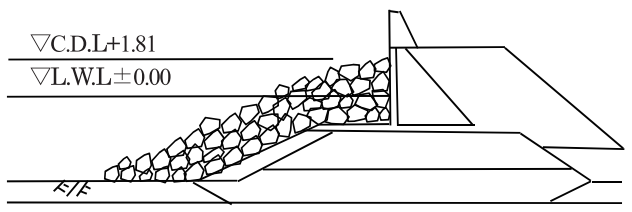

図-3 石積護岸の形状 
集の変遷にどのような影響を及ぼしているのかを明らか にすることを目的とした.

\section{2. 調査の方法}

生物共生護岸の調査を 2010 年 9 月，2011年3月および6 月に実施した (以後 造成から 15 年後調査)。異なる形 状の護岸ごとに調査点を設け，付着生物の目視観察およ びC.D.L.-1m と C.D.L.-3m の護岸前面における付着動物, 海藻を採取 $(50 \mathrm{~cm} \times 50 \mathrm{~cm})$ した．調査の対象としたの はプレキャスト板を付けていない「直立護岸」, 棚状に プレキャストコンクリート板を取り付けた「棚護岸」, そして石積みの傾斜護岸である「石積護岸」の3つであ る.また, 各生物の観察時に護岸前面の海域において水 温，塩分，DOなどを同時に計測した。なお，施工直後 の1995～1996年に実施したモニタリング調査（以後 造成直後調査）では，1995年 8 月，10月，1996年 1 月， 5 月の計 4 回, 造成から 15 年後調査と同様に異なる形状の 護岸において付着生物の目視観察および採取, ならびに 水質調査を行っている.

\section{3. 調査の結果と考察}

生物共生護岸の前面海域における水温とDOの調査結 果を図-4に示す。下層におけるDOの季節変化は $4.0 〜 8.8$

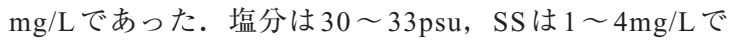
1996年の 5 月が最も高かった。

\section{（1）造成直後と造成 15 年後の生物種組成変化}

直立護岸，棚護岸および石積護岸における付着動物の 個体数, 種類数, 多様度指数についてC.D.L. $-1 \mathrm{~m}$ と C.D.L.-3mの平均を，造成直後ならびに造成から 15 年後 について図-5〜図-7に示す。造成直後の 1995 年 8 月は直 立護岸部や棚護岸においてムラサキイガイが全個体数の 約6割を占め, 他の季節と著しく個体数が異なった。ま

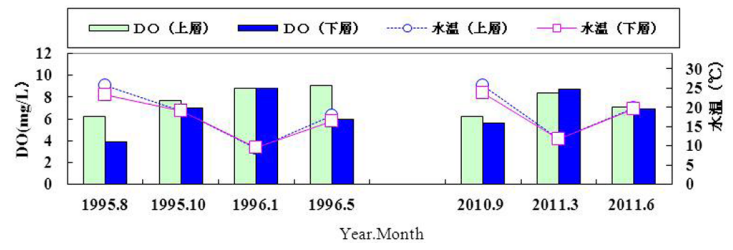

図-4 生物共生護岸前面海域の水質

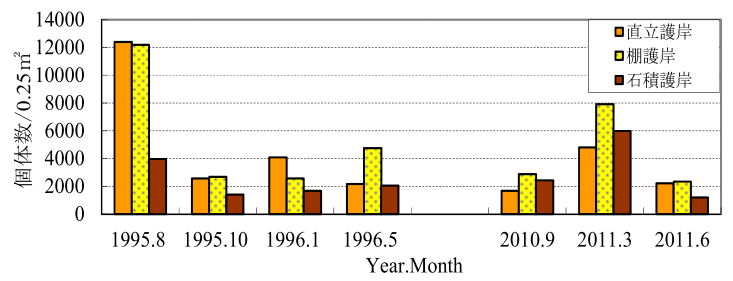

図-5 護岸別付着動物の個体数変動
た，ムラサキイガイにはヒトデが群がり，新たな生息場 の出現という擋乱に対する応答の様子が捉えられた.し かし, 造成から 15 年後の調査では 1995 年 8 月のように個 体数で大差が生じる状況はなく, ムラサキイガイが優占 種になる護岸がほとんどなかった。むしろ，直立護岸， 棚護岸ではムラサキイガイに変わり, サンカクフジッボ が優占種となるケースが増えた。図-5に示すように2011 年3月はいずれの護岸でも個体数が多くなっているが, これはヨコエビ類の出現によるものである. しかし, 造 成から 15 年後では年間を通じて優占種となる付着動物 は，いずれの護岸にもみられなかった.

次に図-6に示す種類数では, 造成直後の調査では直立 護岸や棚護岸が石積護岸に比べて相対的に小さい值を示 したが，造成から 15 年後の調査では全体に高い值で推移 した。この理由として石積護岸ではヨコエビ類やモエビ 類, オウギガニ類など甲款類の増加が影響している. 直 立や棚護岸においてもこれら甲殸類の増加が影響してい るものの, 石積護岸のように通年の出現は, みられなか った.

図-7はShannon-Wienerの多様度指数 $\left(H^{\prime}\right)$ により算出 したものである. 図-7に示す多様度指数 $\left(H^{\prime}\right)$ の変動で は，造成直後および造成から 15 年後の調査ともに石積護 岸の值が，3つの護岸の中で最も変動の幅が小さかった.

$$
H^{\prime}(S)=-\sum_{i=1}^{S}(n i / N) \log _{2}(n i / N)
$$

$S:$ 種類 $n i: i$ 番目の種の個体数 $N$ : 全個体数

これに対し，直立護岸や棚護岸では2010年9月には低い 值を示したものの，2011年3月には石積護岸を上回る值

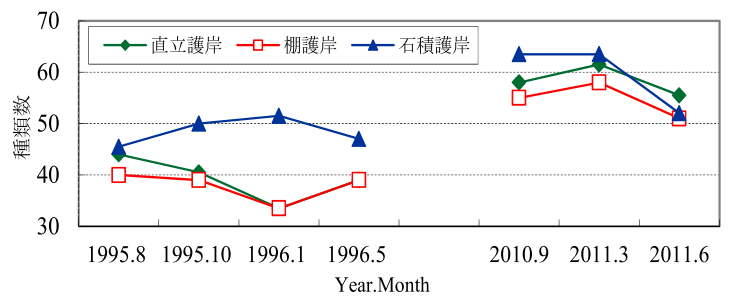

図-6 護岸別付着動物の種類数変動

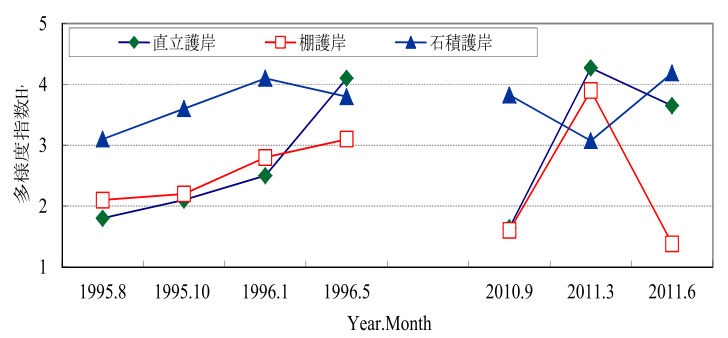

図-7 付着動物の護岸別多様度指数の変動 
を示した。さらに棚護岸では，2011年6月に再び低い值 となり，最も変動が大きかった．2010年9月に直立㧍よ び棚護岸で多様度指数 $\left(H^{\prime}\right)$ が低かったのは, サンカク フジッボの全個体数に対する割合が $52 \%$ 63\%を占め たことがその一因と考えられる。さらに 2011 年 6 月に再 び棚護岸で多様度指数 $\left(H^{\prime}\right)$ が低くなったのは，ムラサ キイガイ，ミズヒキゴカイおよびヒメボヤの 3 種が全個 体数の約6割を占めたことが, 要因と考えられる.

\section{（2）生物群集の機能に着目した評価}

棚護岸および直立護岸においては，これらの造成直後 の 1995 年 8 月と 2010 年 9 月の多様度指数 $\left(H^{\prime}\right)$ は大きな 違いが無いように捉えられる。しかし，1995年8月に観 られた「大量のムラサキイガイとそれに群がるヒトデ」 という特異な状況は2010年9月には認められなかった。 そこで次に図-7に示す多様度指数が，どのような生物相 互の関係に起因しているのかを, 各護岸の付着動物をレ イシガイなどの肉食者, ムラサキイガイなどの賏濁物食 者, ゴカイなどの堆積物食者, そしてヨコエビなどの腐 食雑食者に分けて解析した。とくに1995年 8 月のムラサ キイガイとヒトデの関係が, 新たな生物共生護岸創出と いう環境変化に対する応答として特徵的であったことか ら，ムラサキイガイやサンカクフジッボなどの懸濁物食 者と, ヒトデなど肉食者に着目した．同じ食性内の生物 群は，同様の機能を有すると考えられることから，同じ 機能を果たす生物群が多様であれば，護岸の生態系にお けるその機能が維持されやすいと捉えた。䀣濁物食者内 の多様度指数の変化を相互に比較したものが図-8であ る. 造成直後の調査では, 棚護岸および直立護岸は石積 護岸よりも低く抑えられている。これに対して，造成か ら 15 年後では石積護岸が棚護岸および直立護岸よりも 徐々に低くなり，直立護岸では逆に高まる傾向がみられ た．図-9に示すように懸濁物食者の全個体数に占める優 占種の割合が，造成直後および造成から 15 年後の 2010 年9月にかけて高いことから，棚護岸および直立護岸に おける䀣濁物食者の機能としては，まだ十分整ってない ように捉えられた。次に肉食者の多様度指数の変化を 図-10に示す，造成直後は肉食者としてはヒトデだけが 出現していたため, 棚護岸および直立護岸の多様度指数 はゼロとなっている。しかしながら，造成から 15 年後の 調査では棚護岸および直立護岸にレイシガイなどの肉食 者が複数出現するようになった。とくに2010年 9 月以降 継続してレイシガイなどがみられるようになった直立護 岸では，図-7に示すように，2011年6月も高い多様度指 数が維持されている。一方, 石積護岸で懸濁物食者内の 多様度指数が造成から 15 年後の調查で減少傾向にあった が，この点に関しては海藻との関係に着目した．図-11 は海藻の種類数と湿重量の関係を示したものである. 直

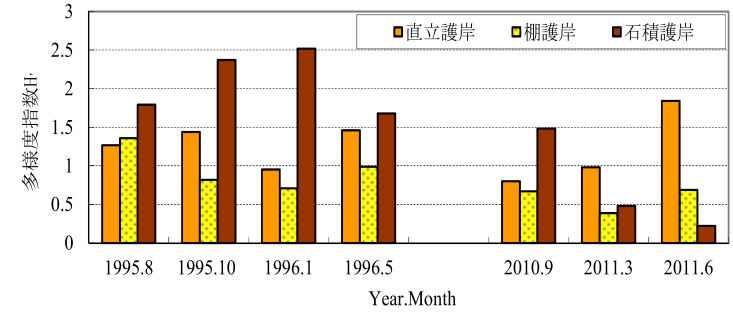

図-8＼cjkstart護岸別懸濁物食者内の多様度指数

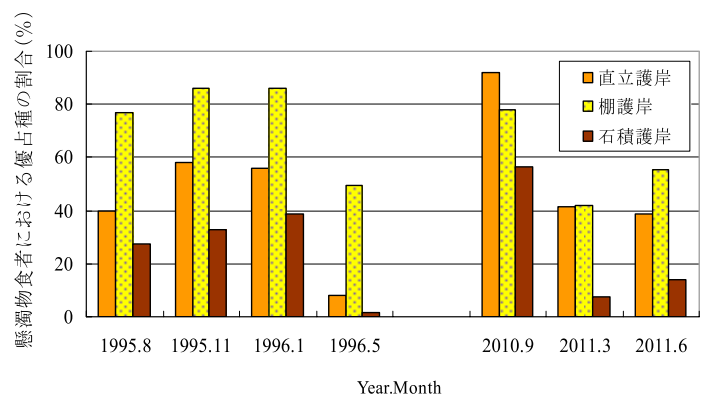

図-9＼cjkstart懸濁物食者における優占種の割合

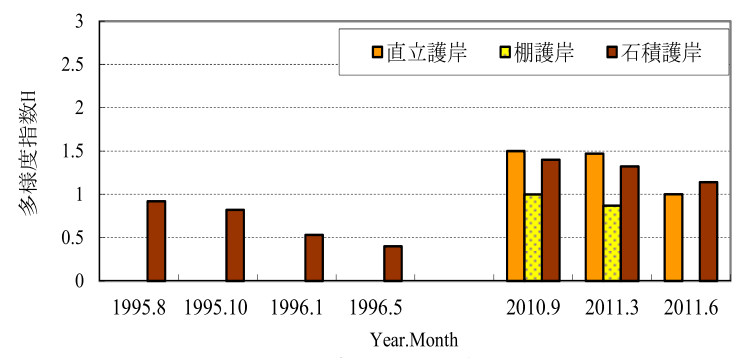

図-10 護岸別肉食者内の多様度指数

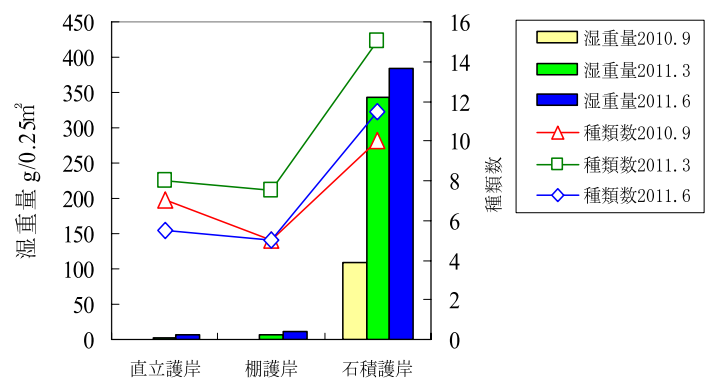

図-11 護岸別海藻の出現状況（造成から 15 年後）

立護岸や棚護岸では出現しているものの, 出現量として は石積護岸の $0.1 \%$ ～ $3.0 \%$ 程度である．石積護岸では 2010 年 3 月から 2011 年 6 月にかけて増加傾向になってい る。これに対し，図-8では同期間，䀣濁物食者の減少が 認められる. よって, 直立護岸や棚護岸では海藻の出現 がごく限られたものであるのに対し，石積護岸では海藻 の繁茂が著しく，懸濁物食者との間に生息空間を奪い合 う関係があったと考えられる。また，造成直後では石積 護岸において懸濁物食者の多様性は高い。これは造成直 
後に石積護岸に繁茂していた優占種が 1 年生のアカモク であったのに対し，造成から 15 年の調査では，優占種が 多年生のマタボウに変わり, 造成直後よりも年間を通じ て懸濁物食者と生息空間において競合する関係にあった と考えられる。

次に生物共生護岸における形状の違いが生物群集の変 遷にどのような影響を及ぼしていのかを分析した。

\section{4. 生物共生護岸における機能の変遷}

\section{（1）棚護岸の生息場としての機能の変遷}

棚護岸では造成直後の 1995 年 8 月や 10 月に直立護岸と 同様にムラサキイガイの大量の発生により，図-7に示す ように多様度指数は低く推移したが，その後は徐々に高 まる傾向が捉えられた．造成から 15 年後では, ヨコエビ 類の増加により, 造成直後にはみられなかった高い多様 度指数を 2011 年 3 月に示した. しかし, その後は低下し, 調查対象の護岸の中でもっとも変動が大きかった。これ については，例えば懸濁物食者に着目した場合，図-8に 示すように直立護岸に比べ懸濁物食者の多様性が低く, すなわち護岸の生物群集の中で眯濁物食者が果たすべき 機能が相対的に低いため, 環境変化への適応が不安定で あったことが一因と考えられる。一方, 肉食者は造成直 後はヒトデの出現に限られ多様度指数がゼロであった が，造成から 15 年後の調査では, 図-10に示すようにレ イシガイやイボニシなどの出現により肉食者の多様性が 高まる様子もみられた。よって, 造成直後に比べ造成か ら 15 年後では，肉食者による懸濁物食者の分布拡大を抑 制する機能は向上していると考えられる。また，付着面 としては同じ垂直面でありながら，直立護岸と違う傾向 を示した理由には，ムラサキイガイなどの付着後の落下 が，関係していると考えられる，直立護岸では付着した ムラサキイガイが成長し，重量が高まるとともに，重み に耐えかねて垂直面に付着していたムラサキイガイの群 れが海底に落下する。一方, 棚護岸ではひさし状のコン クリート板により, 同様に落下したムラサキイガイがコ ンクリート板上に蓄積される。このため，ムラサキイガ イはコンクリート板上から，調査対象としている垂直面 に再び生息範囲を拡大できるチャンスが生じる。したが って, 直立護岸ではムラサキイガイの付着が拡大しても, 海底に落下することで, 護岸の垂直面には他の生物が移 入するチャンスが発生するが, 棚護岸では直立護岸に比 ベ，長い期間ムラサキイガイが生息しやすい環境が維持 される。このため, 他の生物の侵入が制限され, 全体と しての多様度指数が向上しにくい構造にあったと考えら れる.

しかし, 評価指標を変えると棚護岸には興味深い機能 が認められた。付着動物の分析結果には反映されていな
いが，棚護岸のコンクリート板の上には， $15 \mathrm{~cm}$ 以上のマ ナマコに加え, $5 \mathrm{~cm}$ 程度の小型のマナマコも確認されて 打り，水産資源の保全に寄与することが捉えられた。ま た，コンクリート板上に落下したムラサキイガイ等が堆 積するということは，海底への有機物付加量を低減する 役割も果たしていると考えられる。いずれも造成直後に は捉えられなかった特徴である. 生物共生護岸における 生態系サービスを維持するためには，さまざまな角度か らの評価が必要である。

\section{（2）石積護岸の生息場としての機能の変遷}

石積護岸では他の護岸に比べると図-7に示すように, 比較的多様度指数の変動が小さかった。この点について は，2つの要因が考えられる。まず，1つ考えられること は, 石積以外の護岸では造成直後は肉食者の出現がヒト デに限られ，多様度指数がゼロであったことから，懸濁 物食者の分布拡大を抑制する機能が低かったと考えられ る。これに対し，石積護岸では図-10に示すように造成 直後および 15 年後とも常にほかの護岸よりも肉食者の多 様性が維持されており, 直立護岸や棚護岸で特徵的であ つた懸濁物食者の分布拡大に対して抑制機能が高かった と考えられる.ささらにもう一つの要因として, 海藻の存 在が関係していると考えられる，棚護岸では造成から 15 年後の 2010 年 9 月および 2011 年 3 月には肉食者内の多様 性が石積護岸に近いにもかかわらず，全体としての多様 度指数は石積護岸のように安定しなかった。これについ ては，海藻の存在が大きいと考えられる．図-11に示す ように石積護岸では，海藻の増加に伴い図-8の懸濁物食 者内の多様性が低下する傾向が読み取れる。石積護岸で は, 海藻の繁茂がムラサキイガイやサンカクフジッボの 拡大抑制として機能したと考えられる。したがって, 石 積護岸の多様度指数の变動が他の護岸に比べて小さく抑 えられていた背景には，ムラサキイガイやサンカクフジ ツボなどの懸濁物食者の分布を抑制する機能として肉食 者による捕食と, 海藻による生息空間の奪い合いの複数 の機能が維持され，全体としての多様性維持に大きく寄 与していると考えられる. 造成直後には石積護岸で最も 繁茂した海藻は 1 年生のアカモクであったが，造成から 15 年後では多年生のマタボウが優占種であった.よって, 石積護岸では, 海藻の優占種の変遷により, 海藻の生育 量の季節変化が 1 年を通じて付着動物の生息に影響を与 え続ける環境が形成されたと考えられる。これが他の護 岸との大きな違いである。したがって, 海藻が光を受け て繁茂しやすくなるよう傾斜を設けた石積護岸は，この 形状の特徵が造成から 15 年経った現在も石積み護岸の生 息場としての特徴を形成し続けていると言える。また， 石積護岸の付着動物の多様度指数は他の護岸に比べて安 定しているが，この点については図-11に示すように季 


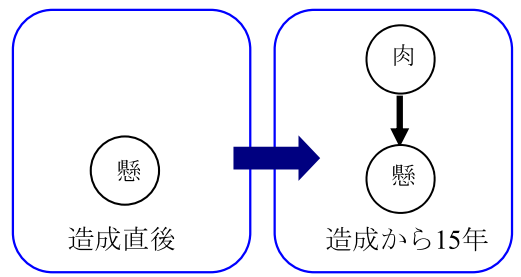

図-12 棚護岸の懸濁物食者に関わる効果の模式

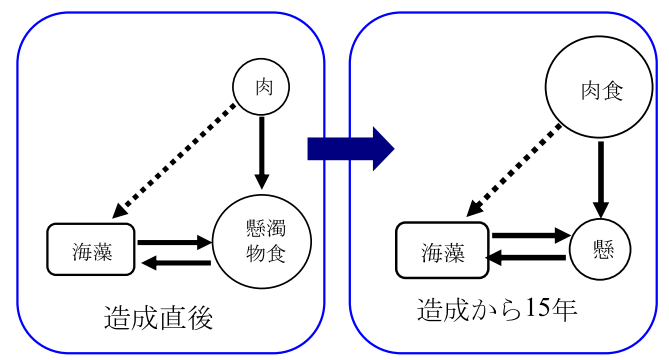

図-13 石積護岸の懸濁物食者に関わる効果の模式

節とともに変化する海藻の出現量にも着目すべきであ る.海藻の形状も含めて石積護岸と捉えたとき, 護岸形 状は常に変化を含んでいる，安定した形状が必ずしもそ こに生息する生物の多様性を高めるとは限らない，規模 としては小さいが生長による海藻の形状変化が擋乱とし て多くの生物の生息チャンスを広げている可能性があ る.ささらに海藻は形状の多様性だけでなく，自ら慨とな り, 物質循環において重要なデトリタス供給源ともなる. その意味において, 護岸を利用して創出した生息場の生 態系サービスを維持する上で海藻は重要な役割を果たし ていると考えられる.

\section{5. 生息場としての機能評価について}

図-12, 図-13 は棚護岸, 石積護岸における懸濁物食者 をめぐる生物相互の模式である（図中肉：肉食者, 懸：懸濁物食者)。肉食者と懸濁物食者の円は, 食性ご との多様度指数を造成直後, 15 年後の各平均值に応じた 大きさで示しており，実線は直接効果，破線は間接効果 を示す．図-12の棚護岸では造成 15 年後に肉食者の多様 性が高まることにより，造成直後には無かった物質の流 れが捉えられる。また，図-13では肉食者による㲘濁物 食者の捕食, 海藻との空間の奪い合い, 肉食者による㲘 濁物食者の分布拡大抑制が間接的に海藻へ空間を提供す るという関係を示している。懸濁物食者の多様性が造成 直後よりも 15 年後に低下した理由として, 肉食者の多様 性向上に伴う相互バランスの変化の影響が図-13からう かがえる. よって, 食性別の多様性の変化を各生物群の 機能の変化として捉えることで, 物質の流れやバランス の変化が見やすくなると考える.
生物共生護岸に期待される生態系サービスには, 付着 基盤や隠水場の提供や，物質循環による水質浄化，漁獲 対象となる水産資源の保全などさまざまな側面があり， いろいろな角度からの評価が必要となる。本研究では本 サービスを支える護岸の機能を評価するため，生息する 生物種の多様性の把握に加え, 食う食われる関係や競争 からなる複雑な相互関係のネットワークの一部の解析を 試みた。生物群集の上位に位置する生物種が安定的に維 持されていれば，その場所の群集構造はある程度豊かで 安定していることが知られている。このため, 生物共生 護岸に生息する肉食者と, とくに造成直後に肉食者との 関係や環境変化に対する応答が速かったムラサキイガイ などの懸濁物食者に着目して, 生息場としての評価を試 みた。その結果, 石積護岸は, 生物種の多様性が比較的 安定しており, また肉食者が通年安定して機能し, 海藻 の繁茂が懸濁物食者との競争を通年維持していることか ら, 棚護岸に比べ, 石積護岸の群集構造は相対的に安定 していると考えられる，多様度指数だけでなく，生物相 互の関係に着目することにより，生息場の生態系サービ スを維持する上で，注目すべき対象種や相互関係が明ら かになると考える.また本生物共生護岸の創出時には, とくにムラサキイガイによる大きな応答があった。これ は東京湾ではムラサキイガイの産卵期が長く, 他の種に 比べて短い期間で環境変化へ対応できる状況があったか らだと思われる，よって，環境の変化に直ちに応答する 生物種の予測は，生息場の創出において重要である.

\section{6. おわりに}

本研究では造成直後の調査から約 15 年を経て, 生物共 生護岸における形状の違いが生物群集の変遷にどのよう な影響を及ぼしたのか，生物多様性に加え生物相互の関 係に着目して調查・分析した。その結果，石積護岸では 海藻が繁茂しやすい構造が, また棚護岸ではひさし状の コンクリート板の存在が, 造成後 15 年経った現在も生息 する生物群集の構造に影響を与え続けていることが捉え られた。よって, 生息域の構造変化が生物群集にもたら す影響を捉えるとき，対象とする生物相互の作用をどの ような空間・時間スケールで捉えるか十分検討した上 で, 生物群集の機能など, 生物相互の関係を考慮するこ とが重要である.

\section{参 考 文 献}

秋山章男・松田道生（1984）：干潟の生物観察ハンドブック， 東洋館出版社, pp.91-180.

大串隆之・近藤倫生・椿 嘉高（2009）：新たな保全と管理を 考える, 京都大学学術出版会, pp.159-168.

沼田 誠 - 風呂田利夫 (1997) : 東京湾の生物誌, 築地書館, pp. $76-85$. 